Article

\title{
Biochar Based Microbial Fuel Cell for Enhanced Wastewater Treatment and Nutrient Recovery
}

\author{
Tyler M. Huggins ${ }^{1}$, Albert Latorre ${ }^{1}$, Justin C. Biffinger ${ }^{2}$ and Zhiyong Jason Ren ${ }^{1, *}$ \\ 1 Department of Civil, Environmental, and Architectural Engineering, University of Colorado, Boulder, \\ CO 80309, USA; michell.huggins@colorado.edu (T.M.H.); albert.latorre@colorado.edu (A.L.) \\ 2 US Naval Research Laboratory, 4555 Overlook Ave. SW., Code 6100, Washington, DC 20375, USA; \\ Justin.biffinger@nrl.navy.mil \\ * Correspondence: zhiyong.ren@colorado.edu; Tel.: +1-303-492-4137
}

Academic Editor: Marc A. Rosen

Received: 17 December 2015; Accepted: 5 February 2016; Published: 14 February 2016

\begin{abstract}
Waste-wood derived biochar was evaluated for the first time as both an anode and cathode material, simultaneously, in an overflow style microbial fuel cell (MFC) using actual industrial wastewater. Results show that the average chemical oxygen demand (COD) removal was 95\% with a reduction rate of $0.53 \mathrm{~kg} \cdot \mathrm{COD} \cdot \mathrm{m}^{-1} \cdot \mathrm{d}^{-1}$ in closed operation mode. The ammonia and phosphorous reductions from wastewater was $73 \%$ and $88 \%$, respectively. Stable power production was observed with a peak power density measured at $6 \mathrm{~W} / \mathrm{m}^{3}$. Preliminary contributions of physical, biological, and electrochemical COD removals were evaluated, and the results show such combined mechanisms give BC an advantage for MFC applications. Nutrient recovery data showed high levels of macronutrients adsorbed onto the spent biochar electrodes, and phosphorus concentration increased from $0.16 \mathrm{~g} \cdot \mathrm{kg}^{-1}$ in raw $\mathrm{BC}$ to up to $1.9 \mathrm{~g} \cdot \mathrm{kg}^{-1}$ in the cathode. These findings highlight the use of biochar as electrodes in MFCs to facilitate simultaneous wastewater treatment and power production with additional agronomic benefits.
\end{abstract}

Keywords: biochar; wastewater treatment; nutrient recovery; microbial fuel cell; sustainability

\section{Introduction}

Microbial fuel cells (MFCs) are a type of bioreactors that utilize the metabolic activity of exoelectrogenic biofilms to convert chemical energy stored in biodegradable materials into an electric current [1]. MFCs have several advantages as a wastewater treatment technology including increased efficiency through mitigated aeration costs, power generation, and decreased sludge production by relying on primarily anaerobic bacteria and fixed biofilms [2,3]. When compared to conventional activated sludge treatment systems, the use of MFC technology results in positive energy output while reducing sludge production by more than $60 \%[4,5]$. When compared to anaerobic digestion, MFCs is more suitable for lower strength wastewater than sludge, and the produced electricity can be directly used without further conversion. MFCs use electroactive bacteria to catalyze the oxidization of organic and inorganic electron donors in the anode chamber and deliver electrons to the anode. The electrons are transferred to the cathode through an external circuit, where they can be harvested as current. MFCs have been used to generate electricity from many different substrates. In addition to simple sugars and derivatives, many complex waste materials, such as different wastewaters, starch, protein, even cellulose and landfill leachates, have also been utilized for simultaneous waste treatment and energy generation [6-8]. Although MFCs show great promise, high material cost is one of the major limitations to larger scale MFC systems due to the unpreventable fouling of the electrode surface [9].

Popular tubular MFC reactors are comprised of two electrode chambers, including an anaerobic anode and an aerobic cathode, each separated by an ion exchange membrane. Of the total construction 
cost, $20 \%-50 \%$ can be attributed to the electrode material $[10,11]$. This has promoted research into finding low cost electrode materials such as activated carbon (AC). Newly developed AC cloth can significantly reduce reactor volume for stacked MFC applications [12], but granular activated carbon (GAC) is a more popularly-used packed bed adsorbent in other wastewater treatment processes, such a biologically activated carbon (BAC) filters. BAC filters have shown to be highly effective at contaminant removal through the combination of both carbon adsorption using GAC and biological degradation [13]. The high adsorption capacity for GAC is primarily attributed to its high surface area and microporosity and its rough surface lends itself to rapid bacterial colonization. However, in both MFC and BAC systems, prolonged use of GAC tends to foul the adsorbent surface, lowering efficiency and requiring replacement [14]. An alternative approach could be to use a similar carbon adsorbent material with a larger pore structure $(>100 \mathrm{~nm})$, helping to limit clogging and prolonging service life.

Wood-derived biochar (BC) is formed from the pyrolysis or gasification of woody biomass that has recently shown great potential as a GAC replacement material for contaminant removal [15]. When this type of biomass is thermally converted it maintains an interconnected three-dimensional structure resembling its original physical morphology [16]. Pyrolysis at higher temperatures $\left(>800{ }^{\circ} \mathrm{C}\right)$ results in the lignin comprised cellular structure to be converted to conductive graphite [17]. These features make $\mathrm{BC}$ a competitive electrode material for MFCs at significantly lower cost than traditional materials such as GAC $[18,19]$. BC has also been shown to have additional carbon sequestration and agronomic benefits when used as a soil amendment [20]. This raises the possibility of using spent BC electrodes as an agricultural amendment, further reducing the environmental burden of MFC operation. Although $\mathrm{BC}$ has been evaluated as both anode and cathode in an MFC, its performance during real wastewater treatment and concurring nutrient recovery has yet to be tested.

In this study we evaluated waste-wood derived biochar electrodes as both anode and cathode material in a tubular overflow style MFC treating real wastewater. Performance was evaluated based on wastewater treatment efficiency, power production, and nutrient content of spent electrodes. The highly conductive biochar material helped to facilitate stable power production using real wastewater substrate while efficiently removing COD $\left(0.53 \mathrm{~kg} \cdot \mathrm{COD} \cdot \mathrm{m}^{-1} \cdot \mathrm{d}^{-1}\right), \mathrm{NH}_{4}(88 \%)$, and $\mathrm{PO}_{4}(73 \%)$. Furthermore, the elemental composition of the spent $\mathrm{BC}$ electrode material after wastewater treatment showed high macronutrient ( $\mathrm{K}, \mathrm{Ca}, \mathrm{Mg}$, and $\mathrm{P}$ ) enrichment.

\section{Results}

\subsection{Physical and Chemical Characterization of BC Electrode Materials}

To help determine the cause of treatment and electrochemical performance, physical and chemical analysis were implemented on the $\mathrm{BC}$ electrode materials. The major physical and elemental characteristics of the $\mathrm{BC}$ materials are presented in Table 1. Based on BET $-\mathrm{N2}$ surface area that measures pore sizes up to $100 \mathrm{~nm}$, it can be seen that the $B C$ has a surface area of $152 \mathrm{~m}^{2} \cdot \mathrm{g}^{-1}$. SEM images reveal larger macropores in the size range of $1-40 \mu \mathrm{m}$ (Figure 1). The large macroporousity of BC can be mainly attributed to the highest heat temperature (HHT) during thermal conversion and to the intrinsic physical structure of the precursor biomass. Previous studies on both wood- and coal-based carbons determined that macroporosity was primarily caused by the pit fields and cell cavities of the source material [21]. A more detailed analysis conducted on the change in molecular structure during the thermal conversion of biomass showed distinct phase changes in the amorphous biomass to more ordered turbostractic char and an increase in BET $-N 2$ surface area with increased temperature $\left(>600^{\circ} \mathrm{C}\right)$ [22]. Further studies on electrochemically active surface area based on normalized current per porous surface area may offer new insights on material optimization [23].

Elemental composition measurements showed a variety of different trace elements imbedded in the carbon matrix (Table 1). The mineral composition of carbon materials can play an important role in the adsorption of various contaminants through both co-precipitation and innersphere complexation [24]. Carbon materials with the appropriate mineral composition should be selected to 
both avoid toxic leaching of metals and the target specific contaminates. $\mathrm{BC}$ has low metal concentration and carries less potential for downstream contamination.
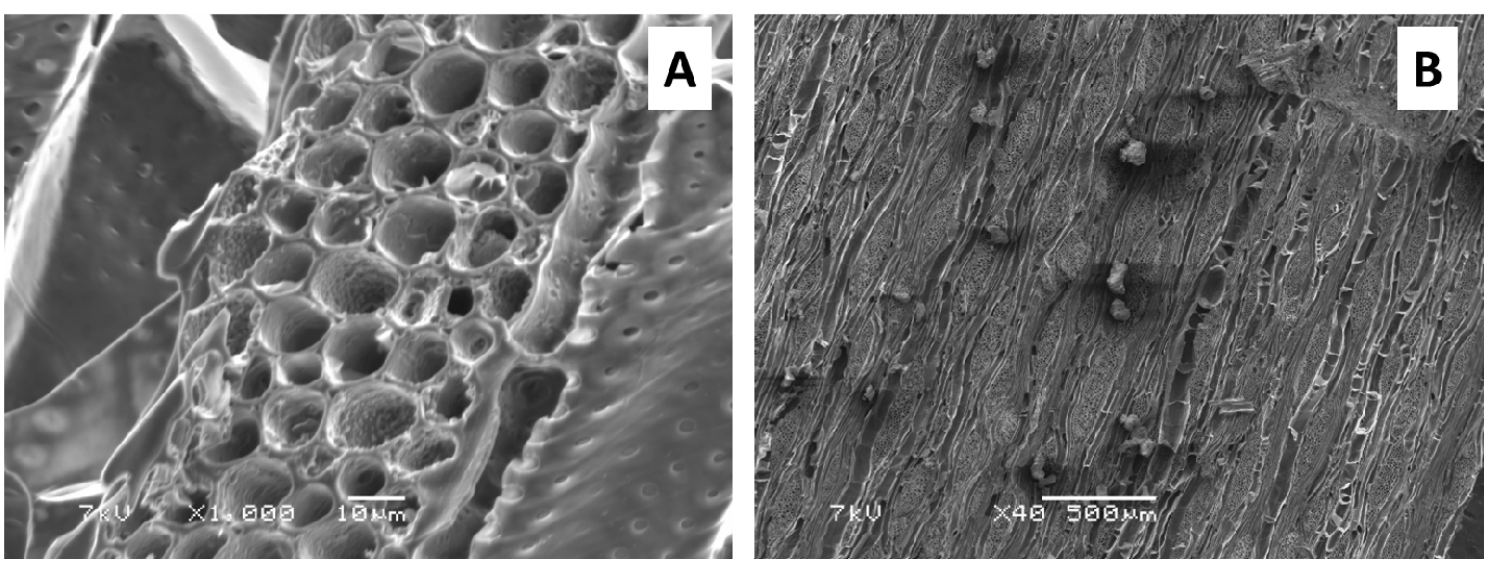

Figure 1. (A) Microscopic and (B) macroscopic SEM images of BC electrode material.

Table 1. Physical and elemental characteristics of biochar (BC) electrode material.

\begin{tabular}{|c|c|c|c|c|c|c|c|c|c|c|}
\hline \multirow{2}{*}{\multicolumn{2}{|c|}{ Material }} & \multirow{2}{*}{ pH } & \multicolumn{2}{|c|}{ Particle Size } & \multicolumn{2}{|c|}{ Specific Gravity } & \multicolumn{2}{|c|}{ BET $\mathrm{N}_{2}$-Total } & \multicolumn{2}{|c|}{ Pore Size Range } \\
\hline & & & \multicolumn{2}{|c|}{$\mathrm{mm}^{3}$} & \multicolumn{2}{|c|}{$\mathrm{g} \cdot \mathrm{cm}^{-3}$} & \multicolumn{2}{|c|}{$\mathrm{m}^{2} \cdot \mathrm{g}^{-1}$} & \multicolumn{2}{|c|}{$(\mu \mathrm{m})$} \\
\hline \multicolumn{2}{|c|}{$\mathrm{BC}$} & 9.66 & $8.0-$ & 4.8 & & & & & & \\
\hline \multicolumn{11}{|c|}{ Elemental composition $\left(\mathrm{mg} \cdot \mathrm{kg}^{-1}\right)$} \\
\hline & $\mathrm{P}$ & K & $\mathrm{Ca}$ & $\mathrm{Mg}$ & As & $\mathrm{Cd}$ & $\mathrm{Cr}$ & $\mathrm{Pb}$ & $\mathrm{Zn}$ & $\mathrm{Cu}$ \\
\hline BC & 106 & 26,143 & 7305 & 878 & 14.3 & 0.16 & 30.0 & 2.3 & 79.4 & 2.9 \\
\hline
\end{tabular}

Resistivity measurements showed that the $\mathrm{BC}$ material is highly conductive with a resistivity of $3.1 \pm 1 \Omega \cdot \mathrm{cm}^{-1}$. The conductivity of carbon materials are a direct consequence of the highest treatment temperature (HTT) [16]. As the feedstock undergoes heat-induced transformation, the organic matter is volatized and there is a gradual increase in graphitic structure. This loss of insulating matter and the formation of more ordered carbon structures increases the electrical conductivity [25]. The BC material used in this study was derived from waste wood at a HHT of $1000^{\circ} \mathrm{C}$ where most biochars are produced a temperature range of $350{ }^{\circ} \mathrm{C}-750^{\circ} \mathrm{C}$. The difference in manufacturing results in the higher conductance of $\mathrm{BC}$ and could serve as an added advantage when used as an electrode material in MFC systems through the avoidance of internal resistance [26].

\subsection{Wastewater Treatment Efficiency of MFC}

To determine the effectiveness of $\mathrm{BC}$ as an electrode for simultaneous real wastewater treatment and power production, a tubular overflow style MFC was operated with granular BC as both the anode and cathode material. Open circuit and closed circuit tests were conducted to evaluate the wastewater efficiency of each mode of operation. The wastewater treatment data can be seen in Figure 2 and the electrochemical data can be seen in Figure 3.

The data collected during the first trial showed that each mode of operation had a similar COD removal rate of around $0.3 \mathrm{~kg} \cdot \mathrm{m}^{-3} \cdot \mathrm{d}^{-1}$. After the second trial, at approximately day 10 and a total of $38 \mathrm{~L}$ wastewater treated, the rate of COD removal began to differentiate with closed circuit generating $0.47 \mathrm{~kg} \cdot \mathrm{m}^{-3} \cdot \mathrm{d}^{-1}$ and open circuit at $0.31 \mathrm{~kg} \cdot \mathrm{m}^{-3} \cdot \mathrm{d}^{-1}$. For the remainder of the experiment closed circuit operation continued to have a higher COD removal rate with a maximum rate at $0.55 \mathrm{~kg} \cdot \mathrm{m}^{-3} \cdot \mathrm{d}^{-1}$ and an average of $0.53 \mathrm{~kg} \cdot \mathrm{m}^{-3} \cdot \mathrm{d}^{-1}$ (Figure 3). Nutrient removal data showed that the closed circuit MFC removed an average of $88 \%$ total $\mathrm{PO}_{4}$ and $73 \% \mathrm{NH}_{4}$ (Figure S2). 


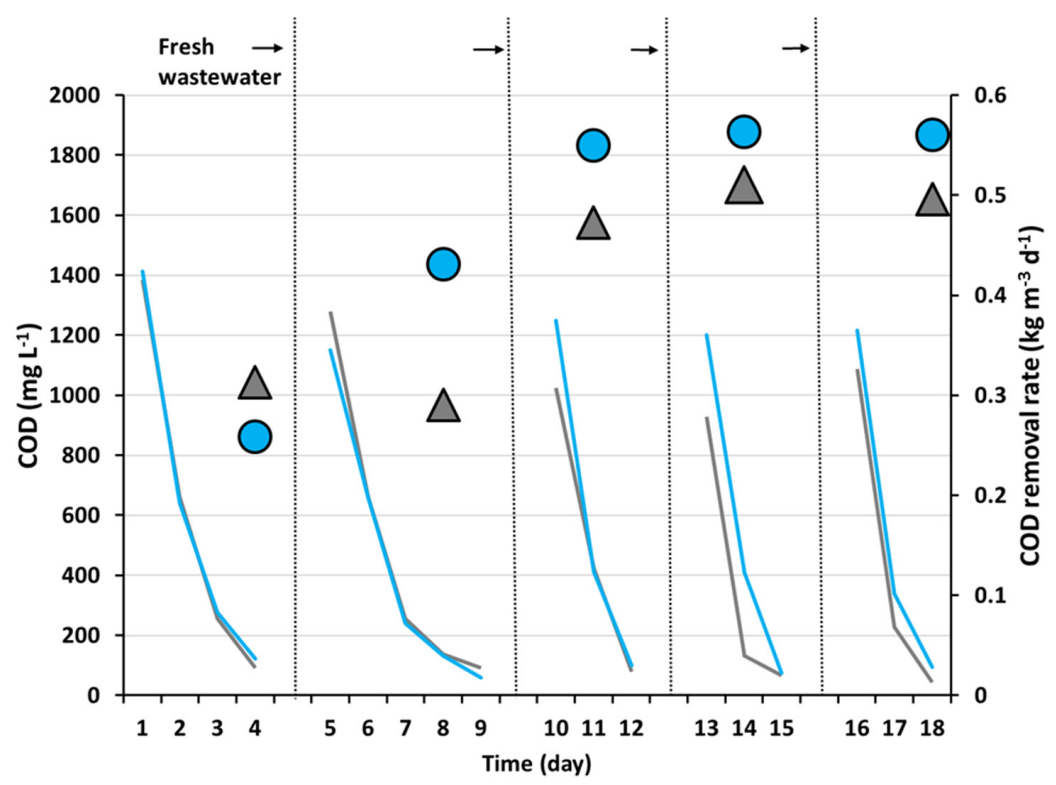

Figure 2. COD concentration (line) and removal rate (symbol) for MFC reactor in closed circuit (blue) and open circuit (gray) treating industrial wastewater.

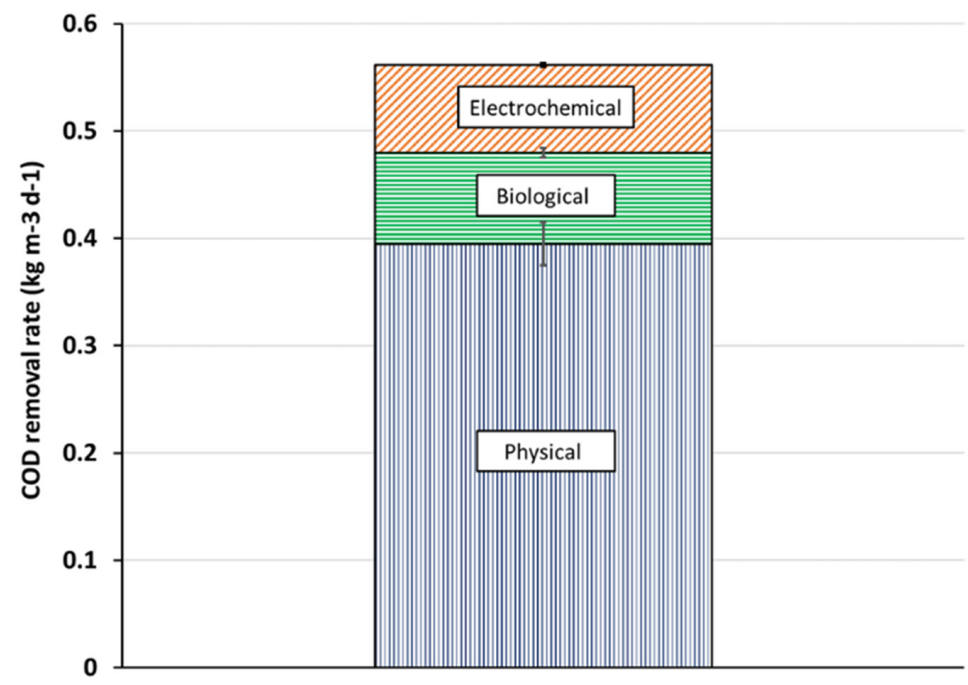

Figure 3. Average COD removal rate contributed to the different wastewater treatment components.

The physical and chemical, biological, and electrochemical contributions of wastewater treatment were calculated from the treatment data and illustrated in Figure 3. The physical and chemical contribution was determined from each initial trial before a biofilm was formed, while the biological component was attributed to the increase in treatment rate during subsequent trials after a biofilm was established. The electrochemical component was calculated from the improved COD removal rate observed in the MFC reactor when run in closed circuit mode and producing a stable current compared to open circuit mode. Based on these calculations, physical and chemical adsorption plays a significant role in treatment, resulting in 39\% of the total COD removal, confirming that the macro-porous structure of $\mathrm{BC}$ can be an alternative material to GAC for wastewater treatment. The biological degradation during open circuit operation represent the removal of COD similar to a biological filter, and it contributes to an additional 17\% COD removal on top of adsorption. The electrochemical component was calculated based on the increased 14\% in COD removal rate during closed circuit operation, when electroactive bacteria boosted organic removal by transferring electrons to the external 
circuit. This preliminary characterization only shows an estimated contribution of different removal mechanisms for COD removal due to the complexity of the actual wastewater and the need of continuous operation. Precise contribution of each mechanism will need further investigations using more defined conditions.

\subsection{Power Production of MFC During Wastewater Treatment}

During the closed circuit wastewater treatment study the power generated from the MFC reactor was also monitored in real time (Figure 4B). Our observations showed that power generation stayed below the detectable limit for approximately 5 days. After 5 days the reactor started producing a power density of $4 \mathrm{~W} \cdot \mathrm{m}^{-3}$ and continued to produce a steady power density of this magnitude for the remainder of the 20 day experiment. At day 10, a maximum power density was typically measured at $6 \mathrm{~W} \cdot \mathrm{m}^{-3}$ (Figure $4 \mathrm{~A}$ ). The steady power production was promising and can be attributed to the high adsorption capacity of the electrode and the readily available nutrient supply to the attached biofilm as seen by similar adsorptive electrode materials [27]. The power output is in the similar order of liter-scale MFC using real wastewater, and further improvement can be conducted by increasing the surface to volume ratio and optimizing flow rate $[28,29]$.
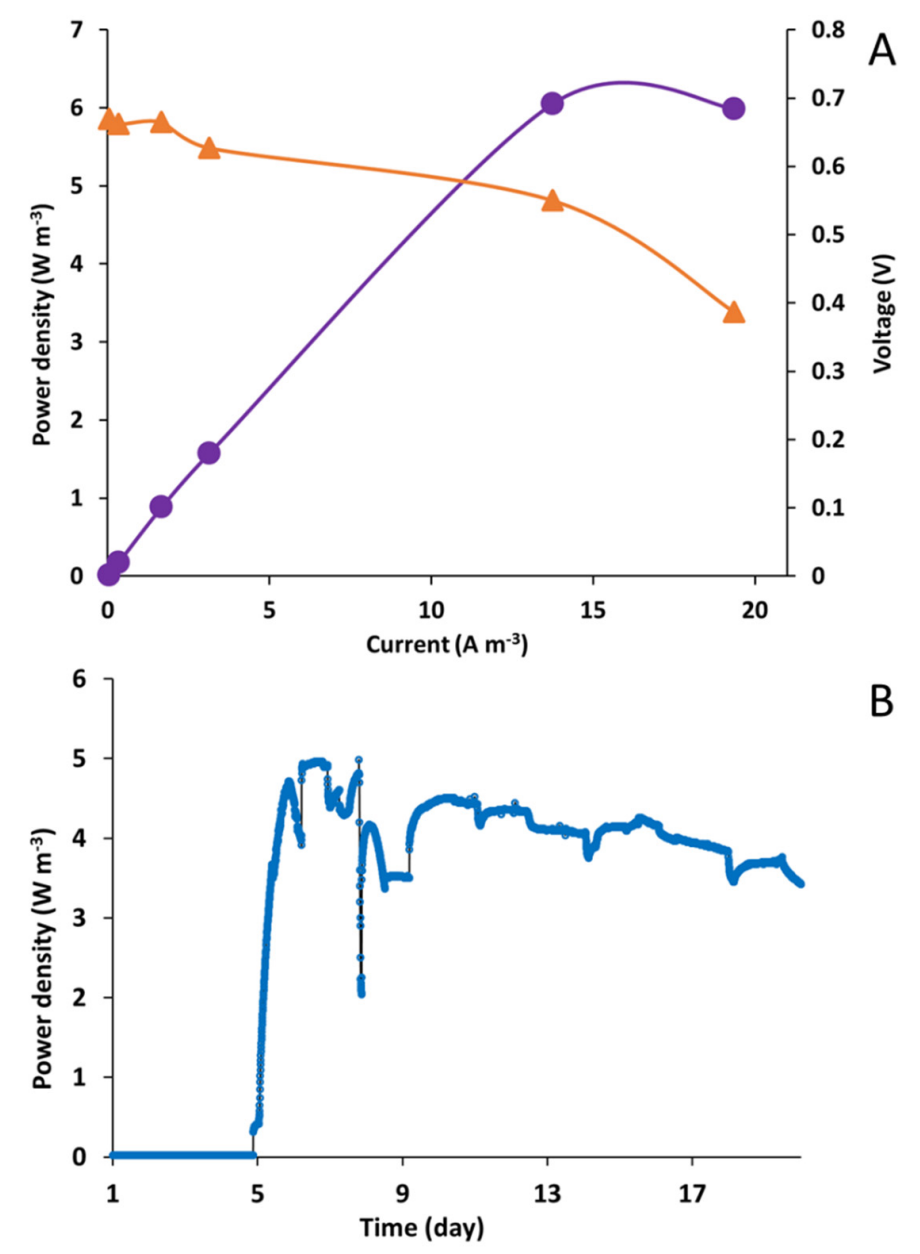

Figure 4. Power density curve (A) and power profile (B) for closed circuit MFC during wastewater treatment.

\subsection{Nutrient Recovery during Wastewater Treatment}

To determine the potential for nutrient recovery through adsorption and retention on the electrode surface, the elemental composition of both the anode and cathode were measured before and after 
each treatment trial. Macronutrient $(\mathrm{K}, \mathrm{Ca}, \mathrm{Mg}$, and $\mathrm{P})$ concentration change and final concentration are illustrated in Figure 5. Based on our findings, it can be seen that the final nutrient composition of both the anode and cathode material remained high. The $\mathrm{P}$ content increased by orders of magnitudes from $0.16 \mathrm{~g} \cdot \mathrm{kg}^{-1}$ in raw $B C$ to $1.9 \mathrm{~g} \cdot \mathrm{kg}^{-1}$ and $0.49 \mathrm{~g} \cdot \mathrm{kg}^{-1}$ of $\mathrm{P}$ for cathode and anode, respectively, after 20 days of operation. In general, the resulting BC material had low concentrations of metals (Figure S3) and were well below the limit for biosolids application in the USA [30]. Compared with GAC, which has to be regenerated or landfilled after wastewater treatment, this data strengthens the possibility of using spent BC electrodes for agricultural purposes after wastewater treatment.

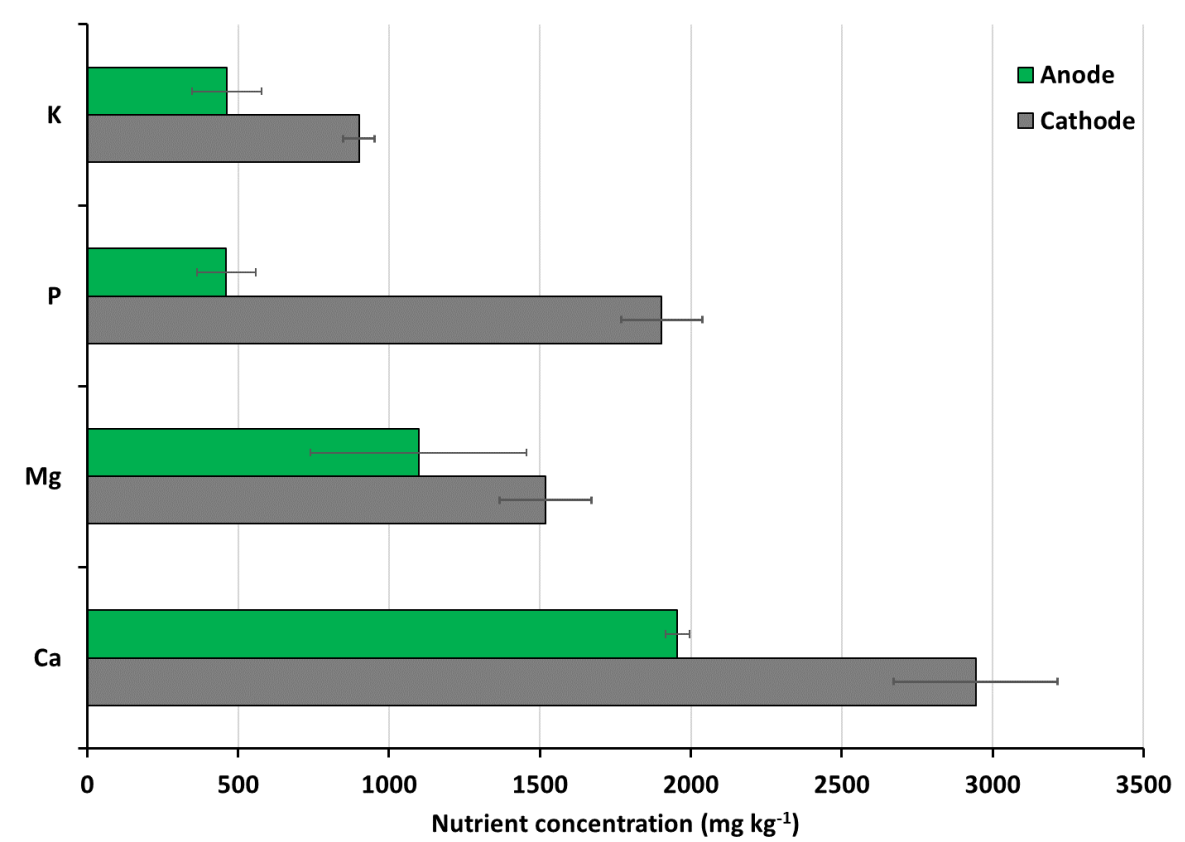

Figure 5. Nutrient concentration for anode (green) and cathode (gray) after wastewater treatment.

\section{Materials and Methods}

\subsection{BC Electrode and Manufacturing Process}

The BC material was prepared from discarded pine wood lumber collected from a construction site and was thermally converted at a highest heat temperature of $1000{ }^{\circ} \mathrm{C}$ for $1 \mathrm{~h}$, in a top-lit up-draft (TLUD) gasifier. Detailed biochar electrode manufacturing process can be found in Huggins et al. [18]. Heat was entirely generated from the chemical energy of the feedstock and no external heat was added to the furnace. The larger pieces of $\mathrm{BC}$ material were crushed to a size range between 4.8 and $8.0 \mathrm{~mm}^{3}$ without any further activation step.

\subsection{Physical, Chemical, and Electrochemical Analyses}

The morphology and structure of the $\mathrm{BC}$ material was investigated using scanning electron microscopy (SEM; Jeol JSM-6480LV, 30 kV). Elemental composition was determined by inductively coupled plasma mass spectrometry (ICP-MS) using a Perkin Elmer SCIEX inductively coupled plasma mass spectrometer [31]. The surface resistance measurements were determined using a four-point probe (Bridge Technology, Chandler Heights, AZ, USA). Specific surface area and pore size distribution was determined using the Brunauer-Emmett-Teller (BET) method via a five-point $\mathrm{N}_{2}$ gas adsorption technique (ASAP 2020; Micromeritics, Norcross, GA, USA) [32]. Wastewater quality measurements (COD, phosphorous $\left(\mathrm{PO}_{4}\right)$, and ammonia $\left(\mathrm{NH}_{4}\right)$ ) were taken for all experiments (Table 2). $\mathrm{COD}, \mathrm{PO}_{4}$, and $\mathrm{NH}_{4}$ concentrations were measured with digester vials (Hach Co., Loveland, $\mathrm{CO}, \mathrm{USA}$ ), according to APHA standards. Total suspended solids (TSS) were measured by filtering wastewater through 
a dry weighed $1 \mu \mathrm{m}$ filter then drying filter at $105^{\circ} \mathrm{C}$. After drying the filter was weighted and TSS concentration was calculated by:

$$
\operatorname{TSS}(\mathrm{mg} / \mathrm{L})=((\mathrm{A}-\mathrm{B}) \times 1000 / \mathrm{C})
$$

where A is the end weight of filter; $\mathrm{B}$ is the initial weight of filter; and $\mathrm{C}$ is the volume of water filtered.

Table 2. Wastewater characteristics.

\begin{tabular}{cc}
\hline Contaminants $\left(\mathbf{m g} \cdot \mathbf{L}^{-1}\right)$ & Average $\left(\mathbf{m g} \cdot \mathbf{~ L}^{-1}\right)$ \\
\hline COD-total $\left(\mathrm{COD}_{\mathrm{T}}\right)$ & $1243 \pm 55$ \\
COD-dissolved $\left(\mathrm{COD}_{\mathrm{D}}\right)$ & $989 \pm 21$ \\
Phosphate $\left(\mathrm{PO}_{4}\right)$ & $18 \pm 2$ \\
Ammonia $\left(\mathrm{NH}_{4}\right)$ & $24 \pm 3$ \\
Total suspended solids (TSS) & $320 \pm 20$ \\
\hline Metals $\left(\boldsymbol{\mu g} \cdot \mathbf{L}^{-\mathbf{1}}\right)$ \\
\hline Arsenic $(\mathrm{As})$ & 4.8 \\
Cadmium $(\mathrm{Cd})$ & 0.07 \\
Chromium $(\mathrm{Cr})$ & 92 \\
Lead $(\mathrm{Pb})$ & 0.76 \\
Zinc $(\mathrm{Zn})$ & 27 \\
Copper $(\mathrm{Cu})$ & 38 \\
\hline
\end{tabular}

\subsection{MFC Construction and Operation}

The overflow style MFC used in this study is illustrated in Figure 6. The anode chamber outer wall was made of a cation exchange membrane (CMI-7000, Membrane International, NJ, USA) with a total volume of $1.0 \mathrm{~L}$ and a stainless steel strip as a current collector. The cathode chamber was located around the anode chamber with a stainless steel mesh outer wall. Each chamber was filled with BC material and was connected through a hydraulic flow.

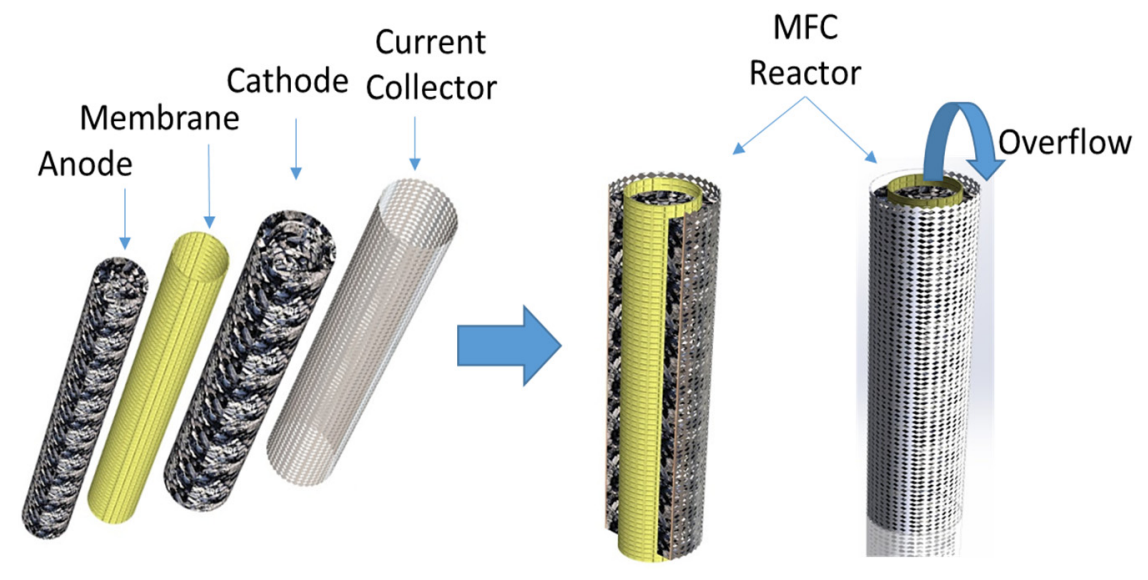

Figure 6. Graphical illustration of packed-bed overflow style MFC used in this study.

Fresh industrial wastewater was collected from Coors Wastewater Treatment Plant in Golden Colorado before each trial. A peristaltic pump was used to circulate wastewater into the anode chamber which passively overflowed into the cathode chamber then to a storage reservoir. A separate peristaltic pump was used to recirculate catholyte and keep the electrodes hydrated. A total volume of $19 \mathrm{~L}$ of wastewater was used for each trial. The total volume of wastewater was replaced once $98 \%$ of the COD was removed. The COD removal rate was normalized by the amount of wastewater treated per anode volume. Two separate reactors were constructed to run in open and closed circuit mode. 
In closed circuit mode, a circuit was created by connecting the anode and cathode with a copper wire and a $100 \Omega$ resistor. Treatment experiments were carried out in replicate during a 20-day period of several repeated cycles. At the end of each experiment, the electrode materials were collected and analyzed for elemental composition.

The cell voltage ( $E$, volt) for the MFC was measured continuously using a data acquisition system (Keithley Instrument, Cleveland, OH, USA) every 66 s. Polarization curves were obtained by varying external resistances from 50,000 to $30 \Omega$ with each resistor stabilized for $30 \mathrm{~min}$ [33]. The anode potential and cathode potential were measured against an $\mathrm{Ag} / \mathrm{AgCl}$ reference electrode (RE-5B, Bioanalysis) inserted in the anode chamber and cathode chamber, respectively (Figure S1). Current (I, amp) was calculated according to $\mathrm{I}=\mathrm{E} / \mathrm{Re}$. Power $(P$, Watt) was calculated according to $P=E \times I$. Current density and power density were normalized by anode chamber volume.

\section{Conclusions}

In this study BC derived from waste wood was evaluated as a granular electrode material in a tubular MFC treating industrial wastewater. Material characterization including SEM images revealed high surface area and macroporosity of the BC material. Open circuit MFC operation using BC electrodes showed improved COD removal efficiency compared to closed circuit, suggesting that the added electrochemical component improves treatment while producing an electrical current. The spent $\mathrm{BC}$ electrodes showed high nutrient concentration and increased $\mathrm{P}$ recovery. Data collected from this study shows the possibility of using BC electrodes in a MFC for simultaneous wastewater treatment, power production, and nutrient recovery.

Supplementary Materials: The following are available online at www.mdpi.com/http://www.mdpi.com/ 2071-1050/8/2/169/s1, Figure S1: Anode (purple) and cathode (blue) potentials during wastewater treatment; Figure S2: $\mathrm{PO}_{4}$ removal (A) and $\mathrm{NH}_{4}$ removal (B) for MFC reactor treating real wastewater; Figure S3: Metals concentrations of both anode (gray) and cathode (green) electrode materials after wastewater treatment.

Acknowledgments: The authors are grateful to Maria Medeiros (ONR, \#N00014-12-1-0293) for financial support through the University Laboratory Initiative and NURP.

Author Contributions: Tyler M. Huggins and Zhiyong Jason Ren conceived and designed the experiments; Tyler M. Huggins and Albert Latorre performed the experiments; Tyler M. Huggins and Albert Latorre analyzed the data; Justin C. Biffinger contributed reagents/materials/analysis tools; Tyler M. Huggins and Zhiyong Jason Ren wrote the paper.

Conflicts of Interest: The authors declare no conflict of interest.

\section{References}

1. Logan, B.E.; Hamelers, B.; Rozendal, R.; Schröder, U.; Keller, J.; Freguia, S.; Aelterman, P.; Verstraete, W.; Rabaey, K. Microbial fuel cells: Methodology and technology. Environ. Sci. Technol. 2006, 40, 5181-5192. [CrossRef] [PubMed]

2. Wang, H.; Ren, Z.J. A comprehensive review of microbial electrochemical systems as a platform technology. Biotechnol. Adv. 2013, 31, 1796-1807. [CrossRef] [PubMed]

3. Li, W.-W.; Yu, H.-Q.; He, Z. Towards sustainable wastewater treatment by using microbial fuel cells-centered technologies. Energy Environ. Sci. 2014, 7, 911-924. [CrossRef]

4. Li, W.W.; Yu, H.Q.; Rittmann, B.E. Chemistry: Reuse water pollutants. Nature 2015, 528, 29-31. [CrossRef] [PubMed]

5. Ren, Z.J.; Umble, A.K. Water treatment: Recover wastewater resources locally. Nature 2016. [CrossRef] [PubMed]

6. Pant, D.; van Bogaert, G.; Diels, L.; Vanbroekhoven, K. A review of the substrates used in microbial fuel cells (MFCs) for sustainable energy production. Bioresour. Technol. 2010, 101, 1533-1543. [CrossRef] [PubMed]

7. Yazdi, H.; Alzate-Gaviria, L.; Ren, Z.J. Pluggable microbial fuel cell stacks for septic wastewater treatment and electricity production. Bioresour. Technol. 2015, 180, 258-263. [CrossRef] [PubMed] 
8. Huggins, T.; Fallgren, P.; Jin, S.; Ren, Z. Energy and performance comparison of microbial fuel cell and conventional aeration treating of wastewater. J. Microb. Biochem. Technol. 2013. [CrossRef]

9. Logan, B.E. Scaling up microbial fuel cells and other bioelectrochemical systems. Appl. Microbiol. Biotechnol. 2010, 85, 1665-1671. [CrossRef] [PubMed]

10. Rozendal, R.A.; Hamelers, H.V.; Rabaey, K.; Keller, J.; Buisman, C.J. Towards practical implementation of bioelectrochemical wastewater treatment. Trends Biotechnol. 2008, 26, 450-459. [CrossRef] [PubMed]

11. Huggins, T.; Wang, H.; Kearns, J.; Jenkins, P.; Ren, Z.J. Biochar as a sustainable electrode material for electricity production in microbial fuel cells. Bioresour. Technol. 2014, 157, 114-119. [CrossRef] [PubMed]

12. Zhang, X.; Pant, D.; Zhang, F.; Liu, J.; He, W.; Logan, B.E. Long-Term Performance of Chemically and Physically Modified Activated Carbons in Air Cathodes of Microbial Fuel Cells. ChemElectroChem 2014, 1, 1859-1866. [CrossRef]

13. Xiaojian, Z.; Zhansheng, W.; Xiasheng, G. Simple combination of biodegradation and carbon adsorption-The mechanism of the biological activated carbon process. Water Res. 1991, 25, 165-172. [CrossRef]

14. Simpson, D.R. Biofilm processes in biologically active carbon water purification. Water Res. 2008, 42, 2839-2848. [CrossRef] [PubMed]

15. Ahmad, M.; Rajapaksha, A.U.; Lim, J.E.; Zhang, M.; Bolan, N.; Mohan, D.; Vithanage, M.; Lee, S.S.; Ok, Y.S. Biochar as a sorbent for contaminant management in soil and water: a review. Chemosphere 2014, 99, 19-33. [CrossRef] [PubMed]

16. Downie, A.; Crosky, A.; Munroe, P. Physical properties of biochar. Biochar Environ. Manag. Sci. Technol. 2009, 2, 13-32.

17. Kercher, A.K.; Nagle, D.C. Microstructural evolution during charcoal carbonization by X-ray diffraction analysis. Carbon 2003, 41, 15-27. [CrossRef]

18. Huggins, T.M.; Pietron, J.J.; Wang, H.; Ren, Z.J.; Biffinger, J.C. Graphitic biochar as a cathode electrocatalyst support for microbial fuel cells. Bioresour. Technol. 2015, 195, 147-153. [CrossRef] [PubMed]

19. Lu, L.; Yazdi, H.; Jin, S.; Zuo, Y.; Fallgren, P.H.; Ren, Z.J. Enhanced bioremediation of hydrocarbon-contaminated soil using pilot-scale bioelectrochemical systems. J. Hazard. Mater. 2014, 274, 8-15. [CrossRef] [PubMed]

20. Woolf, D.; Amonette, J.E.; Street-Perrott, F.A.; Lehmann, J.; Joseph, S. Sustainable biochar to mitigate global climate change. Nat. Commun. 2010. [CrossRef] [PubMed]

21. Wildman, J.; Derbyshire, F. Origins and functions of macroporosity in activated carbons from coal and wood precursors. Fuel 1991, 70, 655-661. [CrossRef]

22. Keiluweit, M.; Nico, P.S.; Johnson, M.G.; Kleber, M. Dynamic molecular structure of plant biomass-derived black carbon (biochar). Environ. Sci. Technol. 2010, 44, 1247-1253. [CrossRef] [PubMed]

23. Sharma, M.; Bajracharya, S.; Gildemyn, S.; Patil, S.A.; Alvarez-Gallego, Y.; Pant, D.; Rabaey, K.; Dominguez-Benetton, X. A critical revisit of the key parameters used to describe microbial electrochemical systems. Electrochim. Acta 2014, 140, 191-208. [CrossRef]

24. Lu, H.; Zhang, W.; Yang, Y.; Huang, X.; Wang, S.; Qiu, R. Relative distribution of Pb 2+ sorption mechanisms by sludge-derived biochar. Water Res. 2012, 46, 854-862. [CrossRef] [PubMed]

25. Kumar, M.; Gupta, R. Electrical resistivity of Acacia and Eucalyptus wood chars. J. Mater. Sci. 1993, 28, 440-444. [CrossRef]

26. Wei, J.; Liang, P.; Huang, X. Recent progress in electrodes for microbial fuel cells. Bioresour. Technol. 2011, 102, 9335-9344. [CrossRef] [PubMed]

27. Zuo, K.; Liang, S.; Liang, P.; Zhou, X.; Sun, D.; Zhang, X.; Huang, X. Carbon filtration cathode in microbial fuel cell to enhance wastewater treatment. Bioresour. Technol. 2015, 185, 426-430. [CrossRef] [PubMed]

28. Feng, Y.; Wang, X.; Logan, B.E.; Lee, H. Brewery wastewater treatment using air-cathode microbial fuel cells. Appl. Microbiol. Biotechnol. 2008, 78, 873-880. [CrossRef] [PubMed]

29. Ge, Z.; Wu, L.; Zhang, F.; He, Z. Energy extraction from a large-scale microbial fuel cell system treating municipal wastewater. J. Power Sources 2015, 297, 260-264. [CrossRef]

30. Mantovi, P.; Baldoni, G.; Toderi, G. Reuse of liquid, dewatered, and composted sewage sludge on agricultural land: effects of long-term application on soil and crop. Water Res. 2005, 39, 289-296. [CrossRef] [PubMed] 
31. Zhu, H.; Wang, H.; Li, Y.; Bao, W.; Fang, Z.; Preston, C.; Vaaland, O.; Ren, Z.; Hu, L. Lightweight, conductive hollow fibers from nature as sustainable electrode materials for microbial energy harvesting. Nano Energy 2014, 10, 268-276. [CrossRef]

32. Lu, L.; Zeng, C.; Wang, L.; Yin, X.; Jin, S.; Lu, A.; Ren, Z.J. Graphene oxide and H2 production from bioelectrochemical graphite oxidation. Sci. Rep. 2015. [CrossRef] [PubMed]

33. Ren, Z.; Yan, H.; Wang, W.; Mench, M.M.; Regan, J.M. Characterization of microbial fuel cells at microbially and electrochemically meaningful time scales. Environ. Sci. Technol. 2011, 45, 2435-2441. [CrossRef] [PubMed]

(C) 2016 by the authors; licensee MDPI, Basel, Switzerland. This article is an open access article distributed under the terms and conditions of the Creative Commons by Attribution (CC-BY) license (http://creativecommons.org/licenses/by/4.0/). 